\title{
Ruminal biohydrogenation and abomasal flow of fatty acids in lactating cows fed diets supplemented with soybean oil, whole soybeans, or calcium salts of fatty acids
}

\author{
J. E. Freitas Jr., ${ }^{*}$ C. S. Takiya, $\uparrow$ T. A. Del Valle, $\uparrow$ R. V. Barletta, $†$ B. C. Venturelli, $\uparrow$ T. H. A. Vendramini, $\dagger$

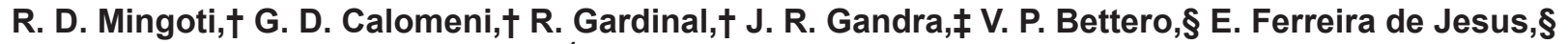 \\ M. D. S. Oliveira, $\S$ and F. P. Rennó $\dagger^{1}$ \\ *Department of Animal Science, Federal University of Bahia, Salvador, Brazil, 0170-110 \\ †Department of Animal Nutrition and Animal Production, University of São Paulo, Pirassununga, Brazil, 13635-900 \\ ‡Department of Animal Science, Federal University of Grande Dourados, Dourados, Brazil, 79825-070 \\ §Department of Animal Science, Sao Paulo State University, Jaboticabal, Brazil, 14884-900
}

\begin{abstract}
Ruminants have a unique metabolism and digestion of unsaturated fatty acids (UFA). Unlike monogastric animals, the fatty acid (FA) profile ingested by ruminants is not the same as that reaching the small intestine. The objective of this study was to evaluate whole raw soybeans (WS) in diets as a replacer for calcium salts of fatty acids (CSFA) in terms of UFA profile in the abomasal digesta of early- to mid-lactation cows. Eight Holstein cows $(80 \pm 20 \mathrm{~d}$ in milk, $22.9 \pm 0.69 \mathrm{~kg} / \mathrm{d}$ of milk yield, and $580 \pm 20 \mathrm{~kg}$ of body weight; mean \pm standard deviation) with ruminal and abomasal cannulas were used in a $4 \times 4$ Latin square experiment with 22 -d periods. The experiment evaluated different fat sources rich in linoleic acid on ruminal kinetics, ruminal fermentation, FA abomasal flow, and milk FA profile of cows assigned to treatment sequences containing a control (CON), with no fat source; soybean oil, added at $2.68 \%$ of diet dry matter (DM); WS, addition of WS at $14.3 \%$ of diet DM; and CSFA, addition of CSFA at $2.68 \%$ of diet DM. Dietary fat supplementation had no effect on nutrient intake and digestibility, with the exception of ether extract. Cows fed fat sources tended to have lower milk fat concentration than those fed CON. In general, diets containing fat sources tended to decrease ruminal neutral detergent fiber digestibility in relation to CON. Cows fed WS had lower ruminal digestibility of DM and higher abomasal flow of DM in comparison to cows fed CSFA. As expected, diets containing fat supplements increased FA abomasal flow of C18:0 and total FA. Cows fed WS tended to present a higher concentration of UFA in milk when compared
\end{abstract}

Received August 10, 2017.

Accepted April 13, 2018.

${ }^{1}$ Corresponding author: francisco.renno@usp.br with those fed CSFA. This study suggests that under some circumstances, abomasal flow of UFA in early lactation cows can be increased by supplementing their diet with fat supplements rich in linoleic acid, regardless of rumen protection, with small effects on ruminal DM digestibility.

Key words: fat source, linoleic acid, milk fatty acid profile, ruminal digestibility

\section{INTRODUCTION}

Polyunsaturated fatty acids are an efficient source of energy and have been used as a tool to modulate the metabolism, reproduction, and immune system of dairy cows (Gandra et al., 2016a,b; Gardinal et al., 2018a,b). In addition, dietary supplementation of PUFA to ruminants has aimed to produce dairy products able to decrease the risk of cardiovascular diseases and obesity in humans (Bauman et al., 2006; Santos et al., 2017; Shokryzadan et al., 2017). However, ruminants are singular in terms of fatty acid (FA) digestion because, unlike monogastric animals, the FA profile ingested by ruminants is not the same as that reaching and absorbed from the small intestine. Rumen microorganisms hydrogenate double bounds within carbon chains to minimize toxic effects of PUFA on rumen bacteria (Oldick and Firkins, 2000), thus limiting the amount of PUFA absorbed by ruminants.

Providing dairy cow diets with rumen-protected fat sources such as calcium salts of fatty acids (CSFA) and oilseeds has increased the amount of PUFA reaching the small intestine. The protein complex surrounding the cotyledon in seeds protects their lipid content from enzymatic biohydrogenation (BH; Doreau et al., 2016). In addition, dietary supplementation of dairy cows with whole flaxseed or whole raw soybeans (WS) has increased milk content of PUFA (Chilliard et al., 
2009; Venturelli et al., 2015). Furthermore, raw oilseeds might be more economically feasible than other PUFA sources, such as CSFA, because they do not undergo industrial processes, thus decreasing nutrient wastes and costs associated with electricity or fuel utilization.

Ruminal passage rate is one of the most important factors determining the extent of ruminal $\mathrm{BH}$ of UFA (Bettero et al., 2017), whereas the lipid FA profile determines the duodenal FA profile (Jenkins and Bridges, 2007). Our research group has published data regarding the ruminal outflow of FA in dry and mid- to latelactation cows fed different sources rich in linoleic acid. Dietary supplementation of WS to dry cows reduced ruminal passage rate of $\mathrm{DM}$ in comparison with cows fed CSFA (2.38 vs. $2.91 \% / \mathrm{h}$, respectively) but did not alter the abomasal flow of C18:2 (Bettero et al., 2017). On the other hand, mid- to late-lactation cows fed WS and CSFA had similar ruminal passage rate of DM (3.1 vs. $3.0 \% / \mathrm{h}$ ), whereas cows fed WS tended to have a greater abomasal flow of C18:2 than those fed CSFA (Barletta et al., 2016). Early- to mid-lactation cows have a relatively high ruminal passage rate of $\mathrm{DM}$, which would influence the response to dietary supplementation of WS and CSFA on abomasal flow of FA.

Gandra et al. (2016b) reported that transition cows fed WS had a higher percentage of neutrophils positive for phagocytosis of Staphylococcus aureus in comparison to those fed CSFA. The positive effects of WS supplementation on the immune system and milk FA profile of early-lactating cows (Gandra et al., 2016a,b; Gardinal et al., 2018a,b) could be supported by an increase in specific FA reaching the small intestine, such as linoleic acid and CLA. Although the ruminal outflow of FA was studied in lactating cows fed WS (Tice et al., 1993, 1994), the authors failed to describe DIM of cows. Thus, literature still lack data regarding the ruminal outflow of FA in early- to mid-lactation cows fed WS.

This study was designed to determine the influence of dietary supplementation of soybean oil (SO), WS, and CSFA on ruminal $\mathrm{BH}$ and FA profile reaching the small intestine in early- to mid-lactating cows. We hypothesized that cows fed SO (unprotected oil) would exhibit greater $\mathrm{BH}$ extent and lower UFA abomasal flow in comparison with cows fed either WS or CSFA (protected oils), whereas we expect similar BH extent and profile of FA in abomasum of cows fed protected oils.

\section{MATERIALS AND METHODS}

The experimental procedures were approved by the Ethics Committee of the School of Veterinary Medicine and Animal Science of the University of São Paulo, São Paulo, Brazil (approval \#1603/2009).

\section{Animals, Experimental Design, and Diets}

Eight multiparous Holstein cows $(80 \pm 20$ DIM, 22.9 $\pm 0.69 \mathrm{~kg} / \mathrm{d}$ of milk yield, $580 \pm 20 \mathrm{~kg}$ of BW; mean $\pm \mathrm{SD}$ ), with ruminal and abomasal cannulas, were allocated to a replicated $4 \times 4$ Latin square experiment with 22-d periods, of which $10 \mathrm{~d}$ allowed for diet adaptation and $12 \mathrm{~d}$ for sampling. Dietary treatments were (1) control (CON), no dietary fat source; (2) SO, added at $2.68 \%$ (DM basis); (3) WS, added at $14.3 \%$; and (4) CSFA (Megalac-E, Church \& Dwight Co. Inc., Trenton, NJ), added at $2.68 \%$. Diets were formulated based on NRC (2001) recommendations (Table 1), supplied twice daily (0600 and $1400 \mathrm{~h}$ ) as TMR, and aiming refusals between 5 and $10 \%$ on an as-fed basis. Formulation of diets with fat sources (SO, WS, and CSFA) targeted a dietary FA content of $45 \mathrm{~g} / \mathrm{kg}$. Corn silage DM was assessed weekly for dietary adjustments when necessary. Treatment sequences were randomly distributed to cows.

Corn silage and concentrate ingredients were collected during each sampling period and pooled into a composite sample per period. Samples were dried in a forced-air oven $\left(55^{\circ} \mathrm{C}\right.$ during $\left.72 \mathrm{~h}\right)$ and ground in a Wiley mill (1-mm screen). Samples were analyzed for NDF using heat-stable $\alpha$-amylase (Van Soest et al., 1991), DM (method \#930.15), ash (method \#942.05), ether extract (EE; method \#920.39), and CP (method \#984.13) according to AOAC International (2000). Nonfiber carbohydrate content was estimated according to Hall (2000), as follows: NFC $=1,000-[(\mathrm{CP}$ $-\mathrm{CP}$ from urea + urea) $+\mathrm{EE}+$ ash $+\mathrm{NDF}]$, all values expressed in grams per kilogram. To determine indigestible NDF (iNDF), samples were ground in a Wiley mill (2-mm screen), placed in nonwoven textile bags tissue $\left(5 \times 5 \mathrm{~cm}\right.$, pore size $\left.50 \mu \mathrm{m}, 100 \mathrm{~g} / \mathrm{m}^{2}\right)$. Bags with ground samples were incubated for $288 \mathrm{~h}$ (Huhtanen et al., 1994) in the rumen of 2 dry cows, previously adapted to the CON diet as described by Casali et al. (2008). Afterward, samples were removed from the rumen, washed in running tap water, and analyzed for NDF concentration as previously described.

Feed samples for FA profile analyses were lyophilized and ground (1-mm screen) with liquid nitrogen to avoid changes in FA profile. Lipid extraction was performed according to Folch et al. (1957) and methylated according to Kramer et al. (1997). Briefly, the lipids were extracted after homogenizing samples with a chloroform and methanol solution $(2: 1, \mathrm{vol} / \mathrm{vol})$. Lipids were 
collected after samples were mixed with $\mathrm{NaCl}$ solution (1.5\%) and centrifuged for $20 \mathrm{~min}$ at $650 \times g$ at $4^{\circ} \mathrm{C}$. Methyl esters from lipids were formed by adding 2 $\mathrm{mL}$ of C19:0 standard solution (as free FA at $1 \mathrm{mg} /$ $\mathrm{mL}$ ) and $2 \mathrm{~mL}$ of sodium methoxide $(0.5 M)$ to lipids, then samples were placed in water bath $\left(50^{\circ} \mathrm{C}\right)$ for 10 min. Samples were cooled and $3 \mathrm{~mL}$ of methanolic $\mathrm{HCl}$ solution (9:1 vol:vol, $3 \mathrm{~mL}$ ) was added, and samples were vortexed and placed in a water bath $\left(80^{\circ} \mathrm{C}\right)$ for 10 min. After samples reached room temperature, $1 \mathrm{~mL}$ of hexane was added, and content transferred to Falcon tubes containing $10 \mathrm{~mL}$ of potassium carbonate solution $(6 \%)$. Falcon tubes were vortexed, centrifuged ( 5 $\min$, at $250 \times g)$, and the organic layer was transferred to test tubes containing $50 \mathrm{mg}$ of sodium sulfide and activated charcoal. Test tubes were centrifuged for 5 $\min \left(250 \times g, 4^{\circ} \mathrm{C}\right)$, rested on ice for $30 \mathrm{~min}$, and the supernatant pipetted into vials for GC analysis.

Methyl-FA were identified and quantified using a gas chromatograph (GC Shimatzu 2010 with automatic injection, Shimadzu Corporation, Kyoto, Japan) equipped with a SP-2560 capillary column $(100 \mathrm{~m} \times$ $0.25 \mathrm{~mm}$ i.d. with $0.02 \mu \mathrm{m}$ film thickness; Supelco Sigma-Aldrich Group, Bellefonte, PA). The following standards were used to identify methyl-FA: C4-C24 (TM 37, Supelco Sigma-Aldrich Group); trans-11 C18:1 (V038-1G, Supelco Sigma-Aldrich Group); trans10,cis-12 C18:2 (UC-61M 100 mg, Nu-Chek Prep Inc., Waterville, MN); and cis-9,trans-11 C18:2 (UC-60M 100 mg, Nu-Chek Prep Inc.).

\section{Nutrient Digestibility}

Refusals from each animal were daily weighed at 0600 $\mathrm{h}$ to determine feed intake. Samples of refusals were collected through the sampling period and composited to per period and cow for further chemical analyses. Refusals were analyzed for DM, NDF, iNDF, CP, EE, and FA, as previously described. Potentially digestible NDF (pdNDF) was calculated as the difference between NDF and iNDF values. Daily DM fecal excretion was estimated based on chromic oxide concentration in feces as described in Harvatine and Allen (2006a). Briefly, 5 $\mathrm{g}$ of chromic oxide $\left(\mathrm{Cr}_{2} \mathrm{O}_{3}\right)$ was provided through ruminal cannula at 0700,1500 , and $2300 \mathrm{~h}$ from d 7 until d 14. Fecal samples were collected directly from the rectum of each cow every $9 \mathrm{~h}$ on d 12, 13, and 14 of each period and composited (on a wet basis) into one sample per cow per period. Feces were analyzed for DM and NDF content as described earlier. Chromic oxide was quantified by flame atomic absorption spectrometry (SpectraAA 220, Varian, Victoria, Australia) according to the manufacturer's recommendations. Dry matter and NDF digestibility were calculated based on feed intake, total daily fecal excretion, and their concentration in feces, as described below:

Fecal excretion $(\mathrm{kg} / \mathrm{d})=$

$$
\frac{\text { Chromic oxide dosed daily }(\mathrm{g} / \mathrm{d})}{\text { Chromic oxide fecal concentration }(\mathrm{g} / \mathrm{kg})} \text {, }
$$

Digestibility coefficient $(\mathrm{g} / \mathrm{kg})=$

$$
\frac{(\text { Intake }(\mathrm{kg} / \mathrm{d})-\text { Fecal excretion }(\mathrm{kg} / \mathrm{d}))}{\text { Intake }(\mathrm{kg} / \mathrm{d})} \times 1,000 \text {. }
$$

\begin{tabular}{|c|c|c|c|c|}
\hline \multirow[b]{2}{*}{ Item } & \multicolumn{4}{|c|}{ Diet $^{1}$} \\
\hline & $\mathrm{CON}$ & $\mathrm{SO}$ & WS & CSFA \\
\hline \multicolumn{5}{|l|}{ Ingredient (\% DM) } \\
\hline Corn silage $^{2}$ & 55.5 & 55.3 & 55.3 & 55.4 \\
\hline Ground corn & 27.9 & 24.9 & 22.4 & 25.4 \\
\hline Soybean meal & 13.4 & 13.9 & 5.19 & 13.9 \\
\hline Soybean oil & & 2.68 & & \\
\hline Whole raw soybean & & & 14.3 & \\
\hline Calcium salts of fatty acids ${ }^{3}$ & & & & 2.68 \\
\hline Sodium bicarbonate & 0.80 & 0.80 & 0.80 & 0.80 \\
\hline Urea & 0.62 & 0.63 & 0.18 & 0.62 \\
\hline Limestone & 0.62 & 0.63 & 0.63 & \\
\hline Dicalcium phosphate & 0.53 & 0.54 & 0.54 & 0.54 \\
\hline Salt & 0.27 & 0.27 & 0.27 & 0.27 \\
\hline Vitamin and mineral $\operatorname{mix}^{4}$ & 0.18 & 0.18 & 0.18 & 0.18 \\
\hline Ammonium sulfate & 0.09 & 0.09 & 0.09 & 0.09 \\
\hline Magnesium oxide & 0.09 & 0.09 & 0.09 & 0.09 \\
\hline \multicolumn{5}{|l|}{$\begin{array}{l}\text { Chemical (\% DM unless } \\
\text { otherwise stated) }\end{array}$} \\
\hline $\mathrm{DM}(\mathrm{g} / \mathrm{kg})$ & 49.7 & 49.8 & 49.9 & 49.8 \\
\hline $\mathrm{OM}$ & 89.6 & 89.6 & 89.5 & 89.8 \\
\hline $\mathrm{NFC}^{5}$ & 37.4 & 35.2 & 34.4 & 35.6 \\
\hline $\mathrm{NDF}$ & 34.8 & 34.4 & 35.3 & 34.5 \\
\hline Indigestible NDF & 10.7 & 10.6 & 10.6 & 10.6 \\
\hline $\mathrm{CP}$ & 16.1 & 16.1 & 15.8 & 16.2 \\
\hline Ether extract & 2.81 & 5.39 & 4.73 & 5.03 \\
\hline Fatty acid & 2.45 & 4.50 & 4.43 & 4.53 \\
\hline Calcium & 0.70 & 0.70 & 0.70 & 0.75 \\
\hline \multicolumn{5}{|l|}{ Fatty acid profile (\%) } \\
\hline C16:0 & 15.5 & 13.0 & 14.3 & 12.0 \\
\hline C18:0 & 3.24 & 6.30 & 9.32 & 3.68 \\
\hline cis-9 C18:1 & 12.8 & 17.1 & 13.5 & 17.3 \\
\hline cis-9,cis-12 C18:2 & 31.4 & 39.6 & 33.2 & 36.8 \\
\hline cis-9,cis-12,cis-15 C18:3 & 6.26 & 5.58 & 5.22 & 4.86 \\
\hline
\end{tabular}

Table 1. Ingredients, chemical composition, and fatty acid profile of experimental diets

${ }^{1}$ Diets: control (CON), whole raw soybean (WS), soybean oil (SO), and calcium salts of unsaturated fatty acids (CSFA).

${ }^{2}$ Corn silage average composition (\% DM): 36.7 DM, 47.7 NDF, 8.02 $\mathrm{CP}, 10.7$ indigestible NDF, and 7.40 ash.

${ }^{3}$ Megalac-E (Church \& Dwight Co. Inc., Trenton, NJ): 11.5\% of calcium.

${ }^{4}$ Contained per kilogram: $120 \mathrm{~g}$ of Ca, $73 \mathrm{~g}$ of P, $30 \mathrm{~g}$ of S, $44 \mathrm{~g}$ of $\mathrm{Mg}$, $340 \mathrm{mg}$ of $\mathrm{Cu}, 1,350 \mathrm{mg}$ of $\mathrm{Zn}, 940 \mathrm{mg}$ of $\mathrm{Mn}, 3 \mathrm{mg}$ of Co, $16 \mathrm{mg}$ of I, $10 \mathrm{mg}$ of Se, 1,064 mg of Fe, 100,000 IU of vitamin A, 40,000 IU of vitamin $\mathrm{D}$, and $60 \mathrm{IU}$ of vitamin $\mathrm{E}$.

${ }^{5}$ Nonfiber carbohydrate $(\% \mathrm{DM})=100-[(\mathrm{CP}-\mathrm{CP}$ from urea + urea) + ether extract + ash $+\mathrm{NDF}]$, from Hall (2000). 


\section{Milk Yield and Composition}

Cows were milked twice daily (0600 and $1530 \mathrm{~h}$ ), milk samples were collected from each cow on d 16, 17 , and 18 of each experimental period and analyzed for fat and protein content by infrared methodology (Lactoscan, Entelbra, Sao Paulo, Brazil). Milk samples were deproteinized according to Broderick and Clayton (1997), analyzed for milk urea nitrogen by a colorimetric method through commercial kits (Bioclin, Belo Horizonte, Brazil) and absorbance measured in a semiautomatic biochemistry analyzer (SBA-200, CELM, Sao Caetano do Sul, Brazil). The FCM was estimated as follows: $3.5 \% \mathrm{FCM}=(0.432+0.165 \times$ milk fat $) \times$ milk yield (kg/d), as described by Sklan et al. (1992). Lipid extraction from milk samples was performed according to Feng et al. (2004) and methylated according to Kramer et al. (1997). Methyl-FA were quantified by GC, as previously described.

\section{Ruminal Dynamics}

Rumen was evacuated on d 20 and 21 at 1300 and $0700 \mathrm{~h}$, respectively. Rumen digesta was weighted out and volume was measured (Harvatine and Allen, 2006a). During the evacuation, $10 \%$ aliquots were sampled to represent ruminal pool and frozen for further chemical analysis. Samples were analyzed for DM, NDF, and iNDF. Indigestible NDF was used as a marker to calculate abomasal DM flow, as follows:

$$
\begin{aligned}
& \text { Abomasal DM flow }(\mathrm{g} / \mathrm{d})= \\
& \frac{\text { iNDF intake }(\mathrm{g} / \mathrm{d})}{\text { iNDF abomasal concentration }(\mathrm{g} / \mathrm{g})} .
\end{aligned}
$$

Samples of abomasal digesta (1,000 g) were collected through simple T-cannulas inserted $10 \mathrm{~cm}$ from the pylorus (Leão and Coelho da Silva, 1980) every $9 \mathrm{~h}$ from d 12 until d 14 (8 samples; 0600, 1500, and 2400 $\mathrm{h}$ on d 12; 0900 and $1800 \mathrm{~h}$ on d 13; and 0300, 1200, and $2100 \mathrm{~h}$ on $\mathrm{d}$ 14). Samples of abomasal digesta were composited into one sample per cow per period. Indigestible NDF concentration in abomasal digesta was assessed as previously described. Ruminal nutrient digestibility was calculated based on nutrient intake, abomasal flow, and concentration in abomasal digesta. Ruminal turnover and digestion and passage rates were calculated according to the following equations (Oba and Allen, 2003):

$$
\begin{aligned}
& \text { Ruminal turnover rate }(\% / \mathrm{h})= \\
& \left(\frac{\text { Intake of component }(\mathrm{kg} / \mathrm{d})}{\text { Ruminal pool of component }(\mathrm{kg})}\right) \times\left(\frac{100 \%}{24 \mathrm{~h} / \mathrm{d}}\right),
\end{aligned}
$$

Passage rate $(\% / \mathrm{h})=$

$$
\frac{\text { Abomasal flow of component }(\mathrm{kg} / \mathrm{d})}{\text { Ruminal pool of component }(\mathrm{kg})} \times\left(\frac{100 \%}{24 \mathrm{~h} / \mathrm{d}}\right) \text {, }
$$

Digestion rate $(\% / \mathrm{h})=$ ruminal turnover rate $(\% / \mathrm{h})$

- passage rate from rumen $(\% / \mathrm{h})$.

\section{Ruminal Fermentation}

Ruminal fluid samples (straining digesta from 5 different sites of the rumen) were collected on $\mathrm{d} 18$ of each experimental period, before (time 0 ), and 2, 4, 6, 8, 10, and $12 \mathrm{~h}$ relative to the morning feeding. After sampling, $\mathrm{pH}$ of ruminal fluid was measured using a digital pH meter (MB-10, Marte Cientifica, Santa Rita do Sapucai, Brazil). Aliquots from ruminal fluid samples $(1.6 \mathrm{~mL})$ were mixed with methanoic acid (98-100\% $\mathrm{H}_{2} \mathrm{CO}_{2}, 400 \mu \mathrm{L}$ ), centrifuged at $7,000 \times g$ for $15 \mathrm{~min}$ at $4^{\circ} \mathrm{C}$, and the supernatant of each sample was frozen for subsequent VFA analysis. Other aliquots from ruminal fluid samples $(2 \mathrm{~mL})$ were mixed with $1 \mathrm{~mL}$ of sulfuric acid $(0.5 M)$ and frozen for $\mathrm{NH}_{3}-\mathrm{N}$ analysis using the colorimetric phenol-hypochlorite method (Broderick and Kang, 1980). Ruminal concentration of VFA was determined according to Erwin et al. (1961) using a gas chromatograph (GC-2014, Shimadzu Corporation) equipped with a capillary column (Stabilwax, Restek, Bellefonte, PA). The gases used in the analyses were helium $(8.01 \mathrm{~mL} / \mathrm{min}$ flow $)$ as the carrier gas, hydrogen (pressure of $60 \mathrm{kPa}$ ) as the fuel gas, and synthetic air (pressure of $40 \mathrm{kPa}$ ) as the oxidizer gas. The steamer temperature was set at $220^{\circ} \mathrm{C}$, the ionization detector flames at $250^{\circ} \mathrm{C}$, and the separation column at $145^{\circ} \mathrm{C}$ for $3 \mathrm{~min}$, which was raised by $10^{\circ} \mathrm{C} / \mathrm{min}$ until it reached $200^{\circ} \mathrm{C}$.

\section{Biohydrogenation Extent}

Samples of refusals, feces, ruminal digesta, and abomasal digesta were ground (1-mm screen) in a knives mill with liquid nitrogen and lyophilized, as previously described. Lipid extraction and methylation were performed according to Folch et al. (1957) and Kramer et al. (1997), respectively. Fatty acids were determined using a gas chromatograph (GC Shimatzu, Shimadzu Corporation), as previously described. Biohydrogenation extent (BE) was calculated according to Jenkins and Bridges (2007) as follows:

$\mathrm{BE}(\mathrm{g} / \mathrm{kg})=\frac{\text { UFA intake }(\mathrm{g} / \mathrm{d})-\mathrm{UFA} \text { abomasal flow }(\mathrm{g} / \mathrm{d})}{\text { UFA intake }(\mathrm{kg} / \mathrm{d})}$. 


\section{Statistical Analysis}

Data were submitted to MIXED procedure of SAS (version 9.2, SAS Institute Inc., Cary, NC) according to the following model:

$$
Y_{i j k l}=\mu+S_{i}+c_{j}\left(S_{i}\right)+P_{k}+D_{l}+e_{i j k l}
$$

where $Y_{i j k l}$ is the dependent variable, $\mu$ is the overall mean, $S_{i}$ is the fixed effect of square (cow group), $c_{j}\left(S_{i}\right)$ is the random effect of cow within square, $P_{k}$ is the fixed effect of period, $D_{l}$ is the fixed effect of diet, and $e_{i j k l}$ is the residual error.

Data regarding ruminal fermentation were analyzed as repeated measures using the MIXED procedure of SAS adding the sampling time points $(0,2,4,6$, 8,10 , or $12 \mathrm{~h}$ relative to the morning feeding) and their interaction (diet by time) as fixed effects to the previous statistical model. Covariance structures (compound symmetry, heterogeneous compound symmetry, unstructured, autoregressive 1, and heterogeneous autoregressive 1) were selected based on Akaike criteria. Differences among diets were analyzed through orthogonal contrasts: C1 (fat supplementation effect):
CON versus fat sources (SO, WS, and CSFA); C2 (effect of FA protection): $\mathrm{SO}$ versus protected fat sources (CSFA and WS); and C3 (effect of protected fat source type): WS versus CSFA. Significance level was set at 0.05 and trends were declared when $0.05<P<0.10$.

\section{RESULTS}

Dietary fat supplementation increased $(P \leq 0.01) \mathrm{EE}$ intake and total-tract digestibility and had no effect $(P$ $\geq 0.15)$ on intake of nutrients and nutrient digestibility (Table 2). Cows fed protected fat sources had lower $(P$ $<0.01)$ EE intake than SO-fed cows, whereas cows fed CSFA exhibited higher $(P=0.04)$ EE intake in relation to those fed WS. Cows fed protected fat sources (WS and CSFA) and SO had similar $(P \geq 0.38)$ nutrient total-tract digestibility. Although fat supplementation had no effect $(P \geq 0.18)$ on milk yield, milk protein, and urea nitrogen concentration, a tendency toward a decrease $(P=0.08)$ in milk fat concentration in relation to CON was observed.

Diets had no effect $(P \geq 0.19)$ on ruminal digesta volume and DM content (Table 3). Further, no differences were detected $(P \geq 0.37)$ on ruminal pool of

Table 2. Effects of different fat supplements (oil, oilseed, and calcium salts) rich in linoleic acid on nutrient intake and digestibility, and milk yield and composition of early- to mid-lactation dairy cows

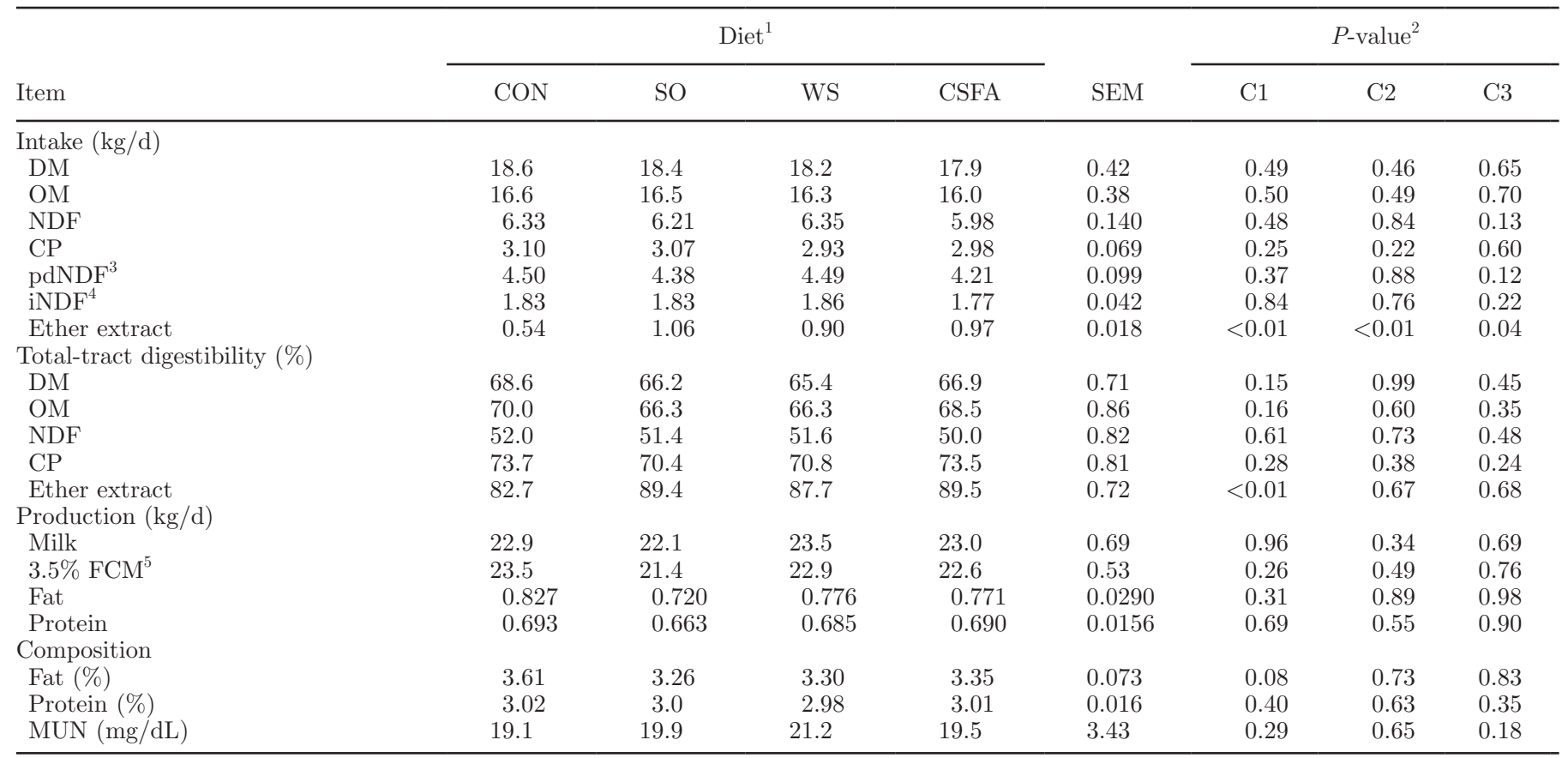

${ }^{1}$ Control (CON); soybean oil (SO), $2.68 \%$ of SO inclusion; whole raw soybeans (WS), $14.3 \%$ of WS addition; and calcium salts of fatty acids (CSFA, Megalac-E, Church \& Dwight Co. Inc., Trenton, NJ), $2.68 \%$ of CSFA supply.

${ }^{2}$ Orthogonal contrasts: $\mathrm{C} 1=\mathrm{CON}$ vs. fat-supplemented diets (SO, WS, and CSFA); $22=\mathrm{SO}$ vs. WS + CSFA; and C3 = WS vs. CSFA.

${ }^{3}$ pdNDF: potentially digestible neutral detergent fiber $=\mathrm{NDF}-$ indigestible NDF.

${ }^{4}$ iNDF: indigestible NDF (288 h - in situ incubation).

${ }^{5} 3.5 \%$ FCM: according to Sklan et al. (1992). 
Table 3. Effects of different fat supplements (oil, oilseed, and calcium salts) rich in linoleic acid on rumen pool, rumen kinetics, ruminal digestibility, and abomasal flow of early- to mid-lactation dairy cows

\begin{tabular}{|c|c|c|c|c|c|c|c|c|}
\hline \multirow[b]{2}{*}{ Item } & \multicolumn{4}{|c|}{$\operatorname{Diet}^{1}$} & \multirow[b]{2}{*}{ SEM } & \multicolumn{3}{|c|}{$P$-value ${ }^{2}$} \\
\hline & $\mathrm{CON}$ & SO & WS & CSFA & & C1 & $\mathrm{C} 2$ & C3 \\
\hline \multicolumn{9}{|c|}{ Rumen digesta } \\
\hline Volume (L) & 76.3 & 78.6 & 75.9 & 73.9 & 1.62 & 0.94 & 0.19 & 0.53 \\
\hline $\mathrm{DM}(\mathrm{g} / \mathrm{kg})$ & 126 & 122 & 128 & 126 & 1.6 & 0.94 & 0.29 & 0.70 \\
\hline \multicolumn{9}{|c|}{ Rumen pool (kg) } \\
\hline $\mathrm{DM}$ & 9.57 & 9.71 & 9.68 & 9.31 & 0.283 & 0.99 & 0.69 & 0.54 \\
\hline OM & 8.82 & 8.96 & 8.89 & 8.59 & 0.271 & 0.99 & 0.67 & 0.62 \\
\hline NDF & 6.84 & 6.88 & 6.73 & 6.64 & 0.203 & 0.84 & 0.64 & 0.85 \\
\hline $\mathrm{iNDF}^{3}$ & 3.36 & 3.49 & 3.47 & 3.34 & 0.084 & 0.37 & 0.62 & 0.54 \\
\hline \multicolumn{9}{|c|}{ Turnover rate $(\% / \mathrm{h})$} \\
\hline $\mathrm{DM}$ & 8.35 & 8.03 & 7.84 & 8.16 & 0.187 & 0.36 & 0.94 & 0.46 \\
\hline NDF & 4.02 & 3.82 & 3.94 & 3.82 & 0.085 & 0.41 & 0.74 & 0.61 \\
\hline iNDF & 2.36 & 2.23 & 2.31 & 2.25 & 0.066 & 0.47 & 0.71 & 0.69 \\
\hline $\mathrm{pdNDF}^{4}$ & 5.64 & 5.58 & 5.77 & 5.44 & 0.155 & 0.91 & 0.94 & 0.45 \\
\hline \multicolumn{9}{|c|}{ Passage rate $(\% / \mathrm{h})$} \\
\hline DM & 3.90 & 4.04 & 3.97 & 3.61 & 0.127 & 0.91 & 0.31 & 0.22 \\
\hline $\mathrm{NDF}$ & 2.04 & 2.20 & 2.27 & 2.17 & 0.084 & 0.42 & 0.93 & 0.67 \\
\hline pdNDF & 1.70 & 2.20 & 2.24 & 2.14 & 0.152 & 0.20 & 0.99 & 0.81 \\
\hline \multicolumn{9}{|c|}{ Digestion rate $(\% / \mathrm{h})$} \\
\hline DM & 4.45 & 3.99 & 3.87 & 4.55 & 0.116 & 0.17 & 0.32 & 0.02 \\
\hline NDF & 2.00 & 1.62 & 1.67 & 1.66 & 0.074 & 0.06 & 0.80 & 0.96 \\
\hline pdNDF & 3.96 & 3.38 & 3.53 & 3.30 & 0.169 & 0.16 & 0.94 & 0.62 \\
\hline \multicolumn{9}{|c|}{ Ruminal digestibility (\%) } \\
\hline $\mathrm{DM}$ & 53.8 & 49.4 & 49.9 & 56.0 & 1.02 & 0.33 & 0.08 & 0.01 \\
\hline NDF & 50.7 & 42.1 & 42.7 & 43.7 & 1.64 & 0.06 & 0.79 & 0.84 \\
\hline pdNDF & 71.7 & 60.1 & 60.6 & 62.1 & 2.34 & 0.07 & 0.82 & 0.82 \\
\hline \multicolumn{9}{|c|}{ Abomasal flow (kg/d) } \\
\hline DM & 8.59 & 9.42 & 9.20 & 7.89 & 0.325 & 0.62 & 0.09 & 0.03 \\
\hline NDF & 3.16 & 3.64 & 3.67 & 3.35 & 0.141 & 0.22 & 0.68 & 0.38 \\
\hline
\end{tabular}

${ }^{1}$ Control (CON); soybean oil (SO), $2.68 \%$ of SO inclusion; whole raw soybeans (WS), $14.3 \%$ of WS addition; and calcium salts of fatty acids (CSFA, Megalac-E, Church \& Dwight Co. Inc., Trenton, NJ), 2.68\% of CSFA supply.

${ }^{2}$ Orthogonal contrasts: $\mathrm{C} 1=\mathrm{CON}$ vs. fat-supplemented diets (SO, WS, and CSFA); $22=\mathrm{SO}$ vs. WS + CSFA; and $\mathrm{C} 3=\mathrm{WS}$ vs. CSFA.

${ }^{3}$ iNDF: indigestible neutral detergent fiber $(288 \mathrm{~h}-$ in situ incubation).

${ }^{4}$ pdNDF: potentially digestible neutral detergent fiber $=$ neutral detergent fiber - indigestible neutral detergent fiber.

DM, OM, NDF, and iNDF. Fat supplements tended to decrease the NDF digestion rate $(P=0.06)$ and ruminal digestibility of $\mathrm{NDF}(P=0.06)$ and $\operatorname{pdNDF}(P=$ $0.07)$. Regarding rumen-protected fat sources, cows fed WS exhibited greater $(P=0.03)$ abomasal flow of DM, and smaller $(P \leq 0.02)$ DM digestion rate and ruminal digestibility than those fed CSFA.

Diets had no effect $(P \geq 0.17)$ on all ruminal parameters assessed ( $\mathrm{pH}$ and VFA proportions) with the exception of ruminal concentration of $\mathrm{NH}_{3}-\mathrm{N}$, which was decreased $(P=0.04)$ by dietary fat supplementation (Table 4). As expected, dietary fat supplementation increased $(P<0.01)$ FA intake (including C16:0, C18:0, cis-9 C18:1, cis-9,cis-12 C18:2, and cis-9,cis12, cis-15 C18:3) of cows (Table 5). Interestingly, cows fed SO had greater $(P \leq 0.022)$ intake of $\mathrm{C} 18: 0$, cis-9 $\mathrm{C} 18: 1$, cis-9,cis-12 C18:2, and cis-9,cis-12,cis-15 C18:3 compared with those fed rumen-protected fat sources.
Feeding WS increased $(P \leq 0.04)$ the intake of $\mathrm{C} 16: 0$, C18:0, and cis-9,cis-12,cis-15 C18:3 but decreased $(P$ $\leq 0.02$ ) the intake of cis-9 $\mathrm{C} 18: 1$ and cis-9,cis-12 C18:2 compared with when cows were fed CSFA. Although FA intake was greatly affected by experimental diets, fat supplementation only increased $(P \leq 0.05)$ the abomasal flow of C16:0 and C18:0. Soybean oil and rumen-protected fat supplementation resulted in similar FA abomasal flows and extents of $\mathrm{BH}$.

In general, cows fed fat supplements had greater $(P$ $=0.05) \mathrm{C} 13: 0$ milk concentration in relation to $\mathrm{CON}$ (Table 6). Effects of fat supplementation on milk FA profile were dependent on fat source supplied. Rumen protected fat sources tended to increase $(P=0.09) \mathrm{C} 6: 0$ content and decreased $(P<0.01) \mathrm{C} 15: 0$ content in milk compared with SO. Regarding the rumen-protected fat supplements, CSFA increased $(P \leq 0.01)$ C4:0 and C6:0 contents in milk compared with WS. Furthermore, cows 
Table 4. Effects of different fat supplements (oil, oilseed, and calcium salts) rich in linoleic acid on ruminal fermentation of early- to midlactation dairy cows

\begin{tabular}{|c|c|c|c|c|c|c|c|c|c|}
\hline \multirow[b]{2}{*}{ Item } & \multicolumn{4}{|c|}{ Diet $^{1}$} & \multirow[b]{2}{*}{ SEM } & \multicolumn{4}{|c|}{$P$-value ${ }^{2}$} \\
\hline & $\mathrm{CON}$ & $\mathrm{SO}$ & WS & CSFA & & INT & $\mathrm{C} 1$ & $\mathrm{C} 2$ & C3 \\
\hline $\mathrm{NH}_{3}-\mathrm{N}(\mathrm{mg} / \mathrm{dL})$ & 20.1 & 17.0 & 17.3 & 15.5 & 0.79 & 0.90 & 0.04 & 0.73 & 0.41 \\
\hline Total VFA $(\mathrm{m} M)$ & 124 & 119 & 123 & 122 & 2.0 & 0.88 & 0.53 & 0.50 & 0.79 \\
\hline Acetate ( $\%$ of VFA) & 63.8 & 64.1 & 63.9 & 64.8 & 0.40 & 0.17 & 0.38 & 0.71 & 0.21 \\
\hline Propionate ( $\%$ of VFA) & 22.6 & 23.6 & 23.7 & 22.7 & 0.45 & 0.63 & 0.44 & 0.70 & 0.45 \\
\hline
\end{tabular}

${ }^{1}$ Control (CON); soybean oil (SO), $2.68 \%$ of SO inclusion; whole raw soybeans (WS), $14.3 \%$ of WS addition; and calcium salts of fatty acids (CSFA, Megalac-E, Church \& Dwight Co. Inc., Trenton, NJ), 2.68\% of CSFA supply.

${ }^{2}$ Orthogonal contrasts: $\mathrm{C} 1=\mathrm{CON}$ vs. fat-supplemented diets (SO, WS, and CSFA); C2 = SO vs. WS + CSFA; and C3 = WS vs. CSFA. INT $=$ diet by time interaction. Diet had no effect $(P \geq 0.172)$, and time effect $(P<0.0001)$ was observed for all parameters.

fed CSFA tended to exhibit greater $(P \leq 0.08)$ C8:0 and total SFA, and lower cis-9 C18:1 and total UFA content in milk in comparison to cows fed SO.

\section{DISCUSSION}

In agreement with the hypothesis, cows fed either CSFA or WS demonstrated similar FA profiles in abomasal flows as well as similar extents of BH. Surprisingly, this study demonstrated that SO had similar abomasal flow of FA in comparison with rumen-protected fat sources. Although it was expected that SO would decrease the PUFA in profile of FA in abomasum, cows fed SO had greater intake of C18:2 in comparison to WS and CSFA. The greater the intake of a specific FA the greater the odds of increasing its amount in the abomasal/intestinal digesta. For instance, incrementing doses of SO linearly increased the total UFA in duodenal flow of FA in lambs (Kucuk et al., 2004). In addition, CSFA-fed cows had a greater intake of C18:2 than those fed WS. These effects might be related either to the lower EE content of WS in relation to CSFA (4.73\% vs. $5.03 \%$, respectively) or cows sorting against WS. In the current experiment, SO, WS, and CSFA had $48.9,50.0$, and $42.8 \mathrm{~g} / 100 \mathrm{~g}$ of FA of C18:2 (data not shown). The sorting against WS is supported by the similar DMI and lower EE intake of cows fed WS

Table 5. Effects of different fat supplements (oil, oilseed, and calcium salts) rich in linoleic acid on fatty acid (FA) intake, abomasal flow, and biohydrogenation extent of early- to mid-lactation dairy cows

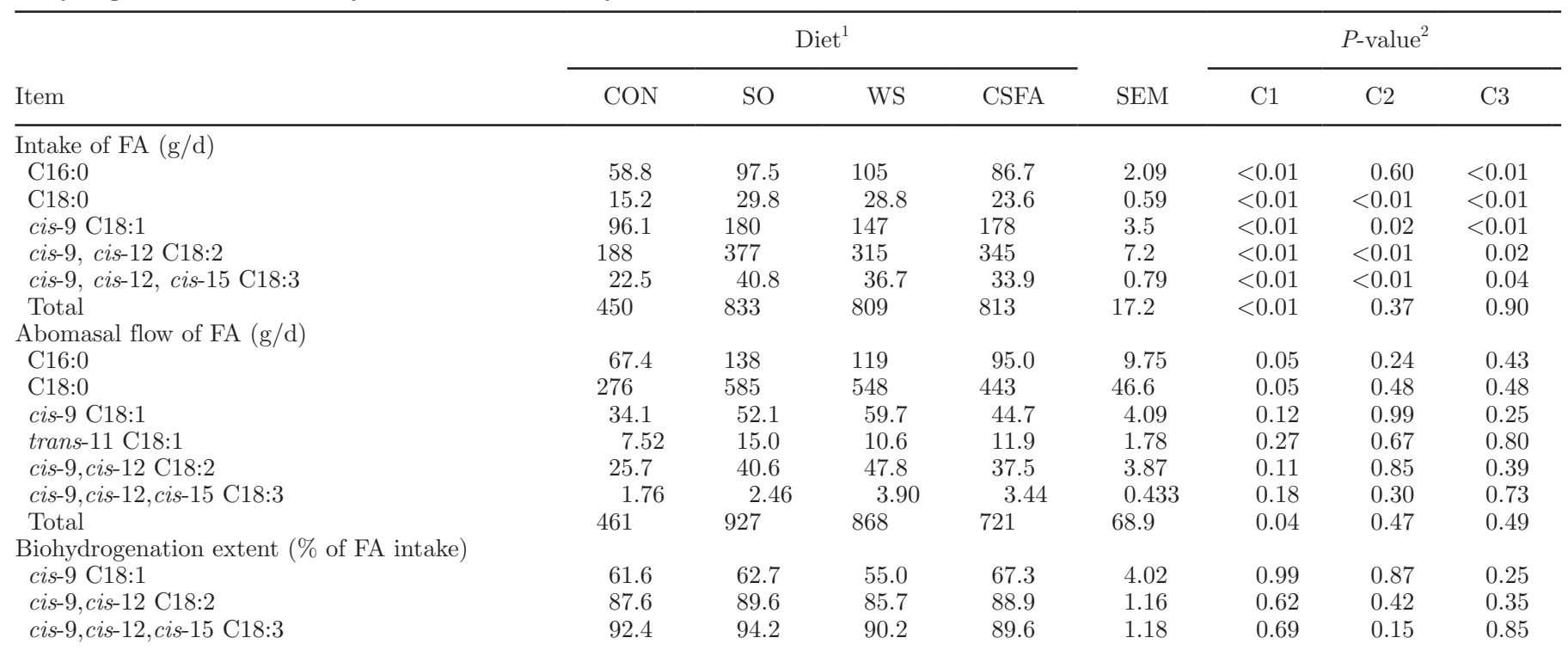

${ }^{1}$ Control $(\mathrm{CON}$ ); soybean oil (SO), $2.68 \%$ of SO inclusion; whole raw soybeans (WS), $14.3 \%$ of WS addition; and calcium salts of fatty acids (CSFA, Megalac-E, Church \& Dwight Co. Inc., Trenton, NJ), 2.68\% of CSFA supply.

${ }^{2}$ Orthogonal contrasts: $\mathrm{C} 1=\mathrm{CON}$ vs. fat-supplemented diets (SO, WS and CSFA); $22=\mathrm{SO}$ vs. WS + CSFA; and C3 = WS vs. CSFA. 
in comparison with those fed SO or CSFA. However, neither Barletta et al. (2016) nor Bettero et al. (2017) reported any sorting effects of WS. Furthermore, the current experiment did not report differences in ruminal passage rate of $\mathrm{DM}$, which affects the time that fat supplements are exposed to microbial $\mathrm{BH}$.

Although high levels of dietary fat can decrease DMI in dairy cows (Allen, 2000), the moderate level of dietary fat used in the current study (almost $4.5 \%$ of FA) was not associated with decreases of feed intake and nutrient digestibility, regardless of fat source added to the diets. Feed intake may be affected by gastrointestinal tract distension, as well as by a high availability of oxidizable fuels in the liver (Allen, 2000). Because dietary effects were neither detected on ruminal passage rate of DM nor on ruminal fermentation in the current study, it is reasonable to find no differences in feed intake of cows. Researchers evaluated the effects of increasing dietary levels of UFA $(2.49,4.29,5.11$, and $5.77 \% \mathrm{FA}$ ) and reported no differences in DMI and digestibility of early- to mid-lactation cows (Benchaar et al., 2012).

Rumen passage rate is determined by physiological status of animals, feed intake level, and ruminal diges- tion rate (particle breakdown processes and microbial activity; Forbes, 1995). This experiment did not show differences either in feed intake or ruminal digestion rate when comparing $\mathrm{SO}$ and protected fat sources. However, CSFA-fed cows had greater digestion rate in comparison with those fed WS, which can be related to the numerically smaller NDF intake of cows fed CSFA. Furthermore, ruminal digestibility and total-tract digestibility of DM were similar between cows fed CON and CSFA. According to Jenkins and Bridges (2007), one of the goals of protecting fat is to decrease the negative effects of FA on ruminal fermentation and nutrient degradation. Few studies have compared the effects of oilseeds and CSFA on NDF ruminal digestibility. Barletta et al. (2016) did not report significant differences in ruminal NDF digestibility between lactating cows fed WS or CSFA. On the other hand, Bettero et al. (2017) found greater ruminal NDF digestibility in dry cows fed WS than those fed CSFA. Differences among these studies might be related to the DM passage rate. For instance, the DM passage rate observed in cows was 3.22 and $2.73 \% / \mathrm{h}$ by Barletta et al. (2016) and Bettero et al. (2017), respectively. Cows in our study exhibited an average DM passage rate of $3.88 \% / \mathrm{h}$.

Table 6. Effects of different fat supplements (oil, oilseed, and calcium salts) rich in linoleic acid on milk fatty acid (FA) profile of early- to mid-lactation dairy cows

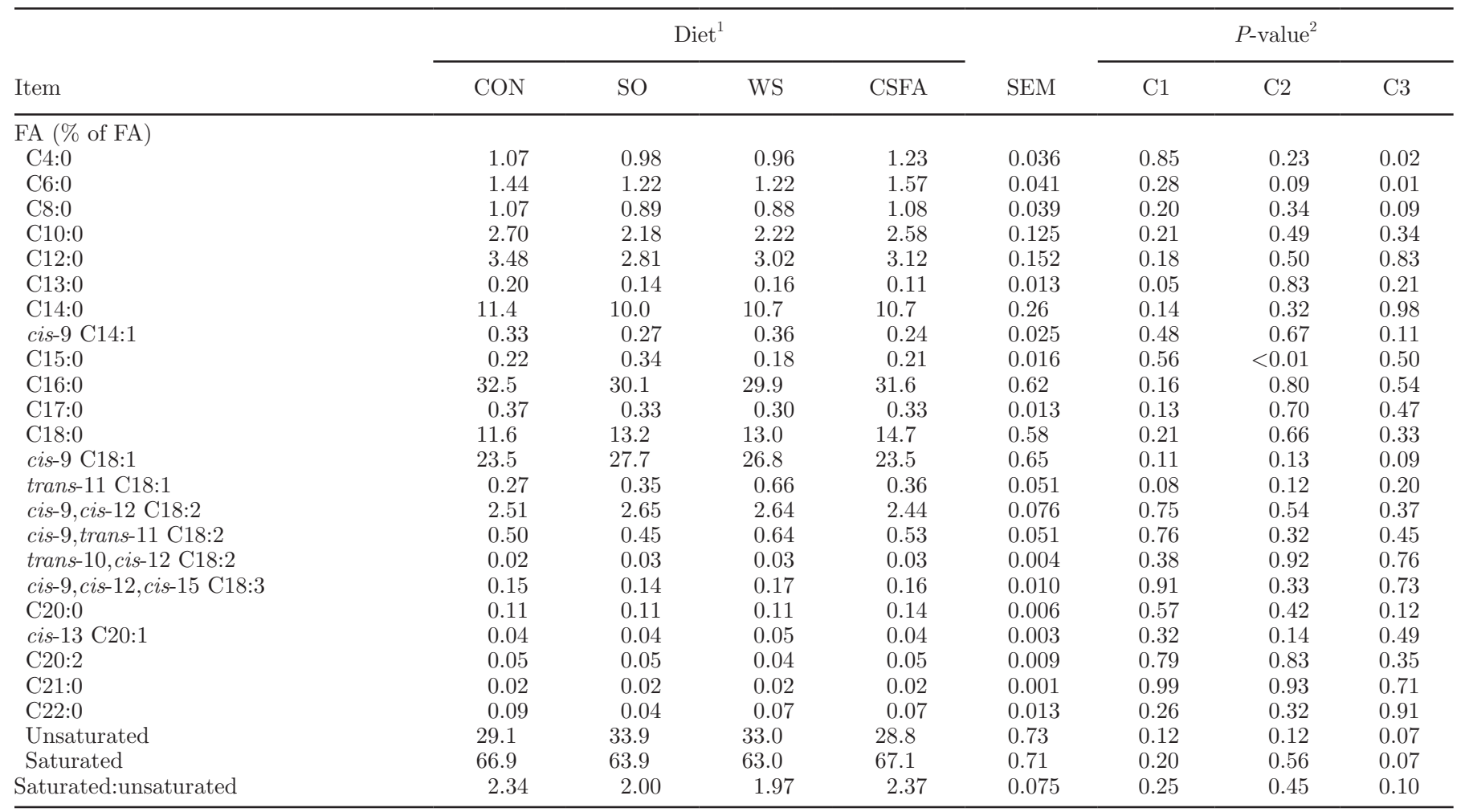

${ }^{1}$ Control $(\mathrm{CON})$; soybean oil (SO), $2.68 \%$ of SO inclusion; whole raw soybeans (WS), $14.3 \%$ of WS addition; and calcium salts of fatty acids (CSFA, Megalac-E, Church \& Dwight Co. Inc., Trenton, NJ), 2.68\% of CSFA supply.

${ }^{2}$ Orthogonal contrasts: $\mathrm{C} 1=\mathrm{CON}$ vs. fat-supplemented diets (SO, WS, and CSFA); $22=\mathrm{SO}$ vs. WS + CSFA; and C3 = WS vs. CSFA. 
Dietary fat supplementation increased the abomasal flow of total FA without affecting abomasal flow of UFA identified in this study. Dietary FA are isomerized and biohydrogenated in the rumen by microorganisms (Jenkins, 1993). Harvatine and Allen (2006b) reported an increase in UFA abomasal flow with fat supplementation. However, these authors found $28.9 \%$ of ruminal DM digestion, which differs from our results (52.3\%). We recruited cows with lower milk yield and ruminal passage rate than those used by Harvatine and Allen (2006b) as these parameters affect abomasal FA flow. It was expected that cows fed SO would exhibit lower UFA abomasal flow in comparison with those fed CSFA and WS, due to the ruminal $\mathrm{BH}$ rate increase when FA as free oil is supplied (Jenkins, 1993; Barletta et al., 2016). Another evidence of this phenomenon is the greater abomasal flow of C18:0, in relation to its intake. According to Jenkins and Bridges (2007), the clearance of $\mathrm{C} 18: 1, \mathrm{C} 18: 2$, and $\mathrm{C} 18: 3 \mathrm{FA}$ in the rumen varies according to the composition of diet, ruminal conditions, feeding levels, marker methods, and geographic location. In this study, in contrast to the findings of Barletta et al. (2016) and Bettero et al. (2017), experimental diets had no effect on ruminal $\mathrm{pH}$, and cows exhibited lower ruminal passage rate compared with passage rates reported by Harvatine and Allen (2006b). We need to highlight that in the present study a single marker technique based on iNDF was used to estimate ruminal outflow, and this technique may not represent the outflow of the fluid phase and small particles, which can be evaluated using the triple marker technique (France and Siddons, 1986).

According to Doreau and Ferlay (1994), the disappearance of C18:3 and C18:2 in the rumen averages 93 and $85 \%$, respectively, which were very similar to values found in the present study. However, diets had no influence on BH extent of C18:1, C18:2, and C18:3. Barletta et al. (2016) reported a decrease on C18:2 BH extent in cows fed protected fat sources, but these authors also reported decreases in ruminal DM passage and NDF digestibility when feeding protected fat sources. Opposing to what has been frequently reported in the literature, results from this experiment suggest that CSFA poorly protect their lipid content from microbial $\mathrm{BH}$ under certain circumstances. Van Nevel and Demeyer (1996) have shown that calcium salts incubated in vitro in ruminal fluid partially protect PUFA content at $\mathrm{pH} 6.9$ but not at $\mathrm{pH}$ 5.9. In the current experiment, ruminal fluid $\mathrm{pH}$ averaged 5.8. In addition, the dissociation of calcium salts of $\mathrm{SO}$ has been positively correlated with decreases in $\mathrm{pH}$ value with an estimated $\mathrm{p} K_{\mathrm{a}}$ value of 5.6 (Sukhija and Palmquist, 1990). Palmquist (1984) also suggested that CSFA were dissociated in rumen fluid and biohydrogenated with $\mathrm{pH}$ less than 6.0 based on the relatively low milk fat content and low proportion of linoleic acid in milk observed in cows fed CSFA. Lundy et al. (2004) reported C18:2 BH extents averaging 92.2 and $89.1 \%$ for mid-lactation cows fed SO and CSFA, respectively, whereas we observed average C18:2 $\mathrm{BH}$ extents of 89.6 and $88.9 \%$ for cows fed $\mathrm{SO}$ and CSFA, respectively. Even though cows used in Lundy et al. (2004) had greater intake of C18:2 FA than cows exhibited in this experiment. In agreement with the current experiment, Jenkins and Bridges (2007) reported that all supplemental fats (either protected or unprotected) are biohydrogenated to a similar extent (C18:1, 86\%; C18:2, 82\%; and C18:3, 86\%). Furthermore, feeding cows with increasing amounts of unprotected fats will increase UFA intestinal flow (Jenkins and Bridges, 2007).

Fatty acids trapped in vegetable cells, the concentrate proportion (Jenkins and Bridges, 2007), and the dietary starch level (Rico et al., 2015) are some of the factors causing variation in $\mathrm{BH}$ extent. Low $\mathrm{pH}$ limits the rate of lipolysis and impairs the isomerization and the reduction of the second double bound in linoleic acid (Chilliard et al., 2007). Low values of ruminal $\mathrm{pH}$ change microbial population, altering usual ruminal $\mathrm{BH}$ routes and formation of key intermediates of linoleic acid BH (Bauman and Griinari, 2003; Shingfield et al., 2010), resulting in increased concentration of conjugated linoleic acid isomers, which may affect milk fat synthesis (Fuentes et al., 2009).

Dietary fat supplementation tended to decrease milk fat concentration, without major effects on milk yield and composition, and solids concentration. The decrease in milk fat concentration was not expected as we did not observe differences in NDF digestibility and acetate-to-propionate ratio in ruminal fluid when comparing cows fed FA sources with those fed the CON diet. In the current study, CSFA showed a milk FA profile very similar to CON, whereas SO and WS tended to increase milk UFA concentration. Many reports are available in the scientific literature of changes in milk FA profile when cows were fed PUFA (Boerman and Lock, 2014; Gandra et al., 2016a). On the other hand, feeding calcium salts rich in linoleic acid or rich in linolenic acid to lactating cows had minor effects on the proportion of these FA in milk fat (Chouinard et al., 1998).

\section{CONCLUSIONS}

In this study, supplementing the diet of early- to midlactation cows with WS resulted in similar abomasal flow of UFA to that in cows fed CSFA, but the abomasal flow of UFA also depends on the level of intake of UFA. Contrary to what has consistently been reported 
in the scientific literature, in this study, both unprotected (SO) and protected fat sources (WS and CSFA) presented similar abomasal flows of UFA in early- to mid-lactation cows. The reason for this is likely related to dissociation of calcium salts in relatively low ruminal $\mathrm{pH}$. Biohydrogenation extent was neither affected by fat supplementation nor whether the fat supplement was protected or not. Finally, this study suggests that under some circumstances, abomasal flow of UFA in early-lactation cows can be increased by supplementing their diet with fat supplements rich in linoleic acid, regardless of rumen protection, with small effects on ruminal DM digestibility.

\section{ACKNOWLEDGMENTS}

The authors acknowledge the University of Sao Paulo (USP) and Dairy Cattle Research Laboratory staff. Authors express gratitude to K. Harvatine (Penn State U.) for support on methods and calculations. Authors are grateful to the São Paulo Research Foundation (Brazil) for partial financial support (grant \#2010/00690-9).

\section{REFERENCES}

Allen, M. S. 2000. Effects of diet on short-term regulation of feed intake by lactating dairy cattle. J. Dairy Sci. 83:1598-1624.

AOAC International. 2000. Official Methods of Analysis. 17th ed. AOAC International, Arlington, VA.

Barletta, R. V., J. R. Gandra, V. P. Bettero, C. E. Araújo, T. A. Del Valle, G. F. Almeida, E. F. Ferreira de Jesus, R. D. Mingoti, B. C. Benevento, J. E. Freitas Junior, and F. P. Rennó. 2016. Ruminal biohydrogenation and abomasal flow of fatty acids in lactating cows: oilseed provides ruminal protection for fatty acids. Anim. Feed Sci. Technol. 219:111-121.

Bauman, D. E., and J. M. Griinari. 2003. Nutritional regulation of milk fat synthesis. Annu. Rev. Nutr. 23:203-227.

Bauman, D. E., I. H. Mather, R. J. Wall, and A. L. Lock. 2006. Major advances associated with the biosynthesis of milk. J. Dairy Sci. $89: 1235-1243$

Benchaar, C., G. A. Romero-Pérez, P. Y. Chouinard, F. Hassanat, M. Eugene, H. V. Petit, and C. Côrtes. 2012. Supplementation of increasing amounts of linseed oil to dairy cows fed total mixed rations: Effects on digestion, ruminal fermentation characteristics, protozoal populations, and milk fatty acid composition. J. Dairy Sci. 95:4578-4590.

Bettero, V. P., T. A. Del Valle, R. V. Barletta, C. E. Araújo, E. Ferreira de Jesus, G. F. Almeida, C. S. Takiya, F. Zanferari, P. G. Paiva, J. E. Freitas Júnior, and F. P. Rennó. 2017. Protected fat sources reduce fatty acid biohydrogenation and improve abomasal flow in dry dairy cows. Anim. Feed Sci. Technol. 224:30-38.

Boerman, J. P., and A. L. Lock. 2014. Effect of unsaturated fatty acids and triglycerides from soybeans on milk fat synthesis and biohydrogenation intermediates in dairy cattle. J. Dairy Sci. 97:7031-7042.

Broderick, G. A., and M. K. Clayton. 1997. A statistical evaluation of animal and nutritional factors influencing concentrations of milk urea nitrogen. J. Dairy Sci. 80:2964-2971.

Broderick, G. A., and J. H. Kang. 1980. Automated simultaneous determination of ammonia and total amino acids in ruminal fluid and in vitro media. J. Dairy Sci. 63:64-75.

Casali, A. O., E. Dettmann, S. C. Valadares Filho, J. C. Pereira, L. T. Henrique, S. G. Freitas, and M. F. Paulino. 2008. Influence of incubation time and particles size on indigestible compounds contents in cattle feeds and feces obtained in situ procedures. Rev Braz. Zootect. 37:335-342.

Chilliard, Y., F. Glasser, A. Ferlay, L. Bernard, J. Rouel, and M. Doreau. 2007. Diet, rumen biohydrogenation, cow and goat milk fat nutritional quality: A review. Eur. J. Lipid Sci. Technol. 109:828-855.

Chilliard, Y., C. Martin, J. Rouel, and M. Doreau. 2009. Milk fatty acids in dairy cows fed whole crude linseed, extruded linseed, or linseed oil, and their relationship with methane output. J. Dairy Sci. 92:5199-5211.

Chouinard, P. Y., V. Girard, and G. J. Brisson. 1998. Fatty acid profile and physical properties of milk fat from cows fed calcium salts of fatty acids with varying unsaturation. J. Dairy Sci. 81:471-481.

Doreau, M., and A. Ferlay. 1994. Digestion and utilization of fatty acids by ruminants. Anim. Feed Sci. Technol. 45:379-396.

Doreau, M., A. Meynadier, V. Fievez, and A. Ferlay. 2016. Ruminal metabolism of fatty acids: Modulation of polyunsaturated, conjugated, and trans fatty acids in meat and milk. R. R. Watson and F. Meester, ed. Handbook of Lipids in Humane Function. AOCS Press, San Diego, CA.

Erwin, E. S., G. J. Marco, and E. M. Emery. 1961. Volatile fatty acid analyses of blood and rumen fluid by gas chromatography. J. Dairy Sci. 44:1768-1777.

Feng, S., A. L. Lock, and P. C. Garnsworthy. 2004. A rapid method for determining fatty acid composition of milk. J. Dairy Sci $87: 3785-3788$

Folch, J., M. Lees, and G. H. Sloane-Stanley. 1957. A simple method for the isolation and purification of total lipids from animal tissues. J. Biol. Chem. 226:497-509.

Forbes, J. M. 1995. Physical limitation of feed intake in ruminants and its interactions with other factors affecting intake. Pages 217-232 in Ruminant Physiology: Digestion, Metabolism, Growth and Reproduction W. Engelhardt, S. Leonhard-Marek, and G. Breves, ed. Ferdinand Enke Verlag, Stuttgart, Germany.

France, J., and R. C. Siddons. 1986. Determination of digesta flow by continuous marker infusion. J. Theor. Biol. 121:105-119.

Fuentes, M. C., S. Calsamiglia, P. W. Cardozo, and B. Vlaeminck. 2009. Effect of $\mathrm{pH}$ and level of concentrate in the diet on the production of biohydrogenation intermediates in a dual-flow continuous culture. J. Dairy Sci. 92:4456-4466.

Gandra, J. R., R. V. Barletta, R. D. Mingoti, L. C. Verdurico, J. E. Freitas Junior., L. J. Oliveira, C. S. Takiya, J. R. Kfoury Junior., M. C. Wiltbank, and F. P. Rennó. 2016b. Effects of whole flaxseed, raw soybeans, and calcium salts of fatty acids on measures of cellular immune function of transition dairy cows. J. Dairy Sci. 99:4590-4606

Gandra, J. R., R. D. Mingoti, R. V. Barletta, C. S. Takiya, L. C. Verdurico, J. E. Freitas Junior, P. G. Paiva, E. Ferreira de Jesus, G. D. Calomeni, and F. P. Rennó. 2016a. Effects of flaxseed, raw soybeans and calcium salts of fatty acids on apparent total tract digestibility, energy balance and milk fatty acid profile of transition cows. Animal 10:1303-1310.

Gardinal, R., G. D. Calomeni, F. Zanferari, T. H. A. Vendramini, C. S. Takiya, H. G. Bertagnon, C. F. Batista, A. M. M. P. Della Libera, and F. P. Rennó. 2018a. Different durations of whole raw soybean supplementation during the pre-partum period: Measures of cellular immune function in transition cows. J. Dairy Sci. 101:661-674.

Gardinal, R., G. D. Calomeni, F. Zanferari, T. H. A. Vendramini, C. S. Takiya, T. A. Del Valle, and F. P. Rennó. 2018b. Different durations of whole raw soybean supplementation during the prepartum period: Milk fatty acid profile, oocyte and embryo quality of early lactating Holstein cows. J. Dairy Sci. 101:675-689.

Hall, M. B. 2000. Calculation of non-structural carbohydrate content of feeds that contain non-protein nitrogen. Bulletin 339, University of Florida. Pages 1-25.

Harvatine, K. J., and M. S. Allen. 2006a. Effects of fatty acids supplements on ruminal and total tract nutrient digestion in lactating dairy cows. J. Dairy Sci. 89:1092-1103.

Harvatine, K. J., and M. S. Allen. 2006b. Fat supplements affect fractional rates of ruminal fatty acid biohydrogenation and passage in dairy cows. J. Nutr. 136:677-685. 
Huhtanen, P., K. Kaustell, and S. Jaakkola. 1994. The use of internal markers to predict total digestibility and duodenal flow of nutrients in cattle given six different diets. Anim. Feed Sci. Technol. 48:211-227.

Jenkins, T. C. 1993. Lipid metabolism in the rumen. J. Dairy Sci. 76:3851-3863.

Jenkins, T. C., and W. C. Bridges Jr.. 2007. Protection of fatty acids against ruminal biohydrogenation in cattle. Eur. J. Lipid Sci. Technol. 109:778-789.

Kramer, J. K. G., V. Fellner, M. E. R. Dungan, F. D. Sauer, M. M. Mossoba, and M. P. Yurawecz. 1997. Evaluating acid and base catalysts in the methylation of milk and rumen fatty acids with special emphasis on conjugates dienes and total trans fatty acids. Lipids 32:1219-1228.

Kucuk, O., B. W. Hess, and D. C. Rule. 2004. Soybean oil supplementation of a high-concentrate diet does not affect site and extent of organic matter, starch, neutral detergent fiber, or nitrogen digestion, but influences both ruminal metabolism and intestinal flow of fatty acids in limit-fed lambs. J. Anim. Sci. 82:2985-2994.

Leão, M. I., and J. F. Coelho da Silva. 1980. Técnica de fistulação de abomaso em bezerros. p. 37. Anais da $17^{\mathrm{a}}$ Reunião Anual da Sociedade Brasileira de Zootecnia. Fortaleza, Brazil. Sociedade Brasileira de Zootecnia, Brasília, Brazil.

Lundy, F. P., III, E. Block, W. C. Bridges Jr., J. A. Bertrand, and T. C. Jenkins. 2004. Ruminal biohydrogenation in Holstein cows fed soybean fatty acids as amides or calcium salts. J. Dairy Sci. $87: 1038-1046$

NRC. 2001. Nutrient Requirements of Dairy Cattle. 7th rev. ed. Natl. Acad. Press, Washington, DC

Oba, M., and M. S. Allen. 2003. Effects of corn grain conservation method on ruminal digestion kinetics for lactating dairy cows at two dietary starch concentrations. J. Dairy Sci. 86:184-194.

Oldick, B. S., and J. L. Firkins. 2000. Effects of degree of fat saturation on fiber digestion and microbial protein synthesis when diets are fed twelve times daily. J. Anim. Sci. 78:2412-2420.

Palmquist, D. L. 1984. Calcium soaps of fatty acids with varying unsaturation as fat supplements for lactating cows. Can. J. Anim. Sci. 64(Supp.):240-241.

Rico, D. E., S. Preston, J. Risser, and K. Harvatine. 2015. Rapid changes in key ruminal microbial populations during the induc- tion of and recovery from diet-induced milk fat depression in dairy cows. Br. J. Nutr. 114:358-367.

Santos, N. W., E. H. Yoshimura, C. E. Mareze-Costa, E. Machado, B. C. Agustinho, L. M. Pereira, M. N. Brito, N. A. Brito, and L. M. Zeoula. 2017. Supplementation of cow milk naturally enriched in polyunsaturated fatty acids and polyphenols to growing rats. PLoS One 12:e0172909.

Shingfield, K. J., L. Bernard, C. Leroux, and Y. Chilliard. 2010. Role of trans fatty acids in the nutritional regulation of mammary lipogenesis in ruminants. Animal 4:1140-1166.

Shokryzadan, P., M. Ali Rajion, G. Y. Meng, L. J. Boo, M. Ebrahimi, M. Royan, M. Sahebi, P. Azizi, R. Abiri, and M. F. Jahromi. 2017. Conjugated linoleic acid: a potent fatty acid linked to animal and human health. Crit. Rev. Food Sci. Nutr. 57:2737-2748.

Sklan, D. R., R. Ashkenazi, A. Braun, A. Devorin, and K. Tabori. 1992. Fatty acids, calcium soaps of fatty acids, and cotton seeds fed to high yielding cows. J. Dairy Sci. 75:2463-2472.

Sukhija, P., and D. L. Palmquist. 1990. Dissociation of calcium soaps of long-chain fatty acids in rumen fluid. J. Dairy Sci. 73:1784-1787.

Tice, E. M., M. L. Eastridge, and J. K. Firkins. 1993. Raw soybeans and roasted soybeans of different particle sizes. 1. Digestibility and utilization by lactating cows. J. Dairy Sci. 76:224-235.

Tice, E. M., M. L. Eastridge, and J. L. Firkins. 1994. Raw soybeans of different particle sizes. 2. Fatty acid utilization by lactating cows. J. Dairy Sci. 77:166-180.

Van Nevel, C. J., and D. I. Demeyer. 1996. Effect of pH on biohydrogenation of polyunsaturated fatty acids and their Ca-salts by rumen microorganisms in vitro. Arch. Tierernahr. 49:151-157.

Van Soest, P. J., J. B. Robertson, and B. A. Lewis. 1991. Methods for dietary fiber, neutral detergent fiber, and nonstarch polysaccharides in relation to animal nutrition. J. Dairy Sci. 74:3583-3597.

Venturelli, B. C., J. E. Freitas Júnior, C. S. Takiya, A. P. C. Araújo, M. C. B. Santos, G. D. Calomeni, R. Gardinal, T. H. A. Vendramini, and F. P. Rennó. 2015. Total tract nutrient digestion and milk fatty acid profile of dairy cows fed diets containing different levels of whole raw soya beans. J. Anim. Physiol. Anim. Nutr. (Berl.) 99:1149-1160. 